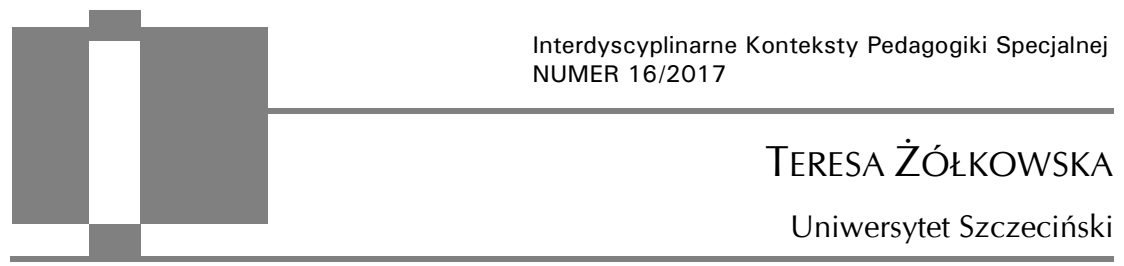

\title{
From communication to humanization of disabled person
}

ABSTRACT: Teresa Żółkowska, From communication to humanization of disabled person [Od komunikacji do humanizacji człowieka niepełnosprawnego]. Interdyscyplinarne Konteksty Pedagogiki Specjalnej, nr 16, Poznań 2017. Pp. 245-255. Adam Mickiewicz University Press. ISSN 2300-391X

The ongoing systemic transformations have intensified the need to update the reflection on (disabled) people, their abilities or even their destiny. The political transformation that took place in our country chanced the scope and forms of social life. Economic and socio-cultural changes led to the disappearance of disabled people. As a result, it is necessary to rebuild a humanistic programme based on embracing the human being, their abilities and capabilities. One of the most important methods of working on the condition and prospects of (disabled) people is undoubtedly communication, and dialogue within its scope.

KEY WORDS: communication, humanization, disabled person

\section{Multidimensional Concept of Humanism}

In line with the threefold subject of this paper and the constant need to bring closer the subject in consideration, a few words need to be said about the main concept of humanism. The term 'humanism' and its many derivatives - humanization, humanities, humanistic world - have all been used in European culture for centuries in relation to (disabled) human being, social or cultural life. Initially, 
these terms were used for describing: a) People studying the ancient culture, and later also: b) Models of education, c) Sciences and their classification, d) Models of social life.

In the twentieth century, a slightly different understanding of the term became widespread. It was used to describe an ideology, a (disabled) man's attitude towards the world and other people. The dynamically developing social, scientific and cultural life that followed, revised the new ideals as well as the manifestation and ways to involve (disabled) people in their determination and promotion. As a result of the constant search for lasting values that organize (disabled) human life, among the truly significant varieties of humanism were those that shaped interpersonal relations and those which affected (disabled) human attitude towards the world, as well as material and spiritual values. As a result, the substantial and semantic scope of these concepts became subject to constant changes and critical evaluation. Particularly strong concerns about the term 'humanism' and its meaning emerged recently, at the turn of the millennium ${ }^{1}$. There is uncertainty as to the scientific nature of this concept, as well as to its methodological and practical reference. Some call for the clarification of the concept along with the methods and subject of research. For the moment, it is neither possible nor necessary to subordinate a very specific subject of (disabled) man to the research methods that are rooted in natural sciences. Towards the end of the last century, these rapidly evolving sciences have dominated the research methodology of other subjects and phenomena, including man. Some natural sciences even interfere with the essence of (disabled) man - in an attempt to improve the human species - as they see fit.

(Disabled) Man is a unique being. Only (disabled) man has the ability to deliberately observe the world, explore it, signify and make sense of it, only he knows oneself, can create and be in the world. Therefore, for the time being, there is no chance of reducing the various components of the humanistic qualities of (disabled)

${ }^{1}$ J. Kozielecki, Transgresje jako źródło kultury, [w:] Humanistyka przełomu wieków, Wydawnictwo Akademickie „Żak”, Warszawa 1999, s. 241-261. 
man, his aspirations, and ideals, to a common denominator, leading to a unified understanding and empirical research. It seems essential that we develop a different methodology for getting to know the modern (disabled) man.

Studies of the historical humanism and its transformations, revealed similarities and differences, perspectives for development, the view of the world and the concept of (disabled) human. Continuous efforts were made to understand the complexity of (disabled) man, the very essence of one's consciousness, needs, aspirations, and ideals ${ }^{2}$. A major contribution to the study of humanism was brought by different trends in philosophy, psychology, and sociology. They provided humanists with knowledge on human (also those disabled) qualities and facilitated their interpretation and evaluation of human experience. The humanization of various sciences, expressed in the attempts to integrate them, contributed to an even broader and deeper knowledge of human (as well as disabled persons) and his fate ${ }^{3}$. Historically shaped views on humanism indicate that: - it established the primacy of (disabled) man and his good among other beings, - in creating the vision of (disabled) human being, it stressed the necessity to refer to universal law, - it drew attention to interpersonal and social relations and commitments as well as fidelity to accepted ideals. It can be said that humanism is a specific reflection on (disabled) man, his view of life based on intertwined currents of philosophy, psychology, anthropology, pedagogy, and even extra-scientific thought. The humanistic world, as is evident from existing reflections, is different from the physical world - it is more subtle, elusive but coherent to the (disabled) human condition and needs. Humanism does not rule out objective cognition and it recognizes (disabled) human experience as the objectivizing criterion most frequently expressed

2 J. Topolski, Przyrodniczy i humanistyczny punkt widzenia w badaniach historycznych, [w:] Humanistyka przełomów wieku, red. J. Kozielecki, Wydawnictwo Akademickie "Żak”, Warszawa 1999, s. 218, 238.

3 J. Strelau, Psychologia. Podręcznik akademicki, Gdańskie Wydawnictwo Naukowe, Gdańsk 2000. 
through verbal communication. It should be taken into account, however, that a verbal, symbolic representation is not an isomorphic message. It encompasses the most narrow and often superficial layer of behaviors that form the focus of human life 4 . For this reason, it is impossible to present the complexity of man through symbols: his love, goodness, beauty, responsibility, pain, sense of action, etc. One must constantly learn how to:

- read behaviors and verbal and nonverbal communication representing signs of concrete intentions which signify something and have a meaning for some,

- read hidden content present in deeper layers of communication, which can also signify and mean something important,

- set the meaning of communication, signs, symbols, assign meaning to them, generate meanings by the cognizer,

- read non-verbal communication.

One must approach the methodology applied to the study of (disabled) man, learning his characteristics and behaviors. Despite many theoretical and methodological doubts, the question of recognizing the condition of modern (disabled) man is of key importance. It is the (disabled) human who forces it, in line with becoming more and more aware of his own identity. It is the (disabled) human and his humanity that form the very essence of humanism.

\section{The timeliness of humanism}

The ongoing systemic changes have resulted in the ethical crisis, while also increasing the need to update the reflection on (disabled) man, his fate, and capabilities. The systemic transformation, accel-

${ }^{4}$ H.G. Gadamer, Semantyka i hermeneutyka, [w:] H.G. Gadamer, Rozum, stowo, dzieje. Szkice wybrane, wybrał K. Michalski, Warszawa 2000; Idem, Prawda i metoda, Wydawnictwo Naukowe PWN, Warszawa 2007; J. Gnitecki, Metodologia badań w pedagogice hermeneutycznej: hermeneutyczna zmiana formacyjna w pedagogice, Wydawnictwo Naukowe PTP, Poznań 2007; M. Heidegger, Bycie i czas, Wydawnictwo Naukowe PWN, Warszawa 2007. 
erated in our country, has unified the various spheres and forms of social life. This primarily included technics, technology, communication. These transformations evoked an illusion of easy life in the minds of people. Due to the ever more efficient technology ${ }^{5}$ as well as multiple and sparkling new offerings, the cult of consumerism has emerged. This is where the (disabled) man and his fate got lost. The postmodern concepts of (disabled) man, characterized by his need of new experience, novelty, short time of being with the object, focus on pleasure - shifted the existing patterns, norms, deeper needs and values to the margins of social life. Therefore, it now seems necessary to penetrate into the (disabled) human being, his capacities, and the possibility of creating new image of the society.

The postulate of the precursors of postmodernism to remove (disabled) human from the program of the new humanities (that could be taken from the Age of Enlightenment, based on the great narrative) and to remove all that is brought in by his deliberate, conscious activity, the dialectic of the Spirit, the hermeneutics of meaning - is rather unacceptable ${ }^{6}$. Otherwise, all the concepts of progress and improvement of (disabled) human fate would be unrealistic. Therefore, there is a need to build a new humanistic program and modernize the centuries-old tradition. It seems justified to acknowledge a few basic assumptions:

- (disabled) human is an integrated individual, so the knowledge of him and his behaviors should not be limited to the selected elements, but rather focus on his entire person;

- (disabled) human has the opportunity to make an informed choice and based on this, shape his own character, behavior, self-responsibility;

- (disabled) human is an intentional being, which is manifested by the formulation of goals, values, reading and assigning

${ }^{5}$ S. Lem, Krótkie uwagi o humanizmie, [w:] Humanistyka przełomów wieku, red. J. Kozielecki, Wydawnictwo Akademickie „Żak”, Warszawa 1999, s. 336-339.

${ }^{6}$ J.F. Lyotard, The Postmodern Condition. A Report on Knowledge, https://www. marxists.org/reference/subject/philosophy/works/fr/lyotard.htm [dostęp: 7.07.2017]; J.F. Lyotard, Fenomenologia, Wydawnictwo KR, Warszawa 2000. 
meaning and sense, and in reading the meanings and sense assigned by others;

- (disabled) human context is the essence of human; his unique nature is expressed through being with others ${ }^{7}$.

The humanity of (disabled) man realizes itself in different situations, especially in those that reveal the relationship between them, towards another (disabled) human, towards differently understood Being, in pursuit of something higher than himself. The study of the authentic manifestations of humanity and the possibility of being (disabled) human can provide an opportunity for approximation of cognitive and axiological perspectives, and help to discover, agree on values, meanings, and sense. It can create empirical facts useful for scientific analysis and evaluation. It can be observed that the proposed program includes content related to (disabled) human being that had been raised since the Socratic times. It has been constantly emphasized that (disabled) man is a social being, a conscious and intentional individual who knows, thinks, hopes and believes, who loves, who does good and evil.

\section{Communication - dialogue - as way of humanizing(disabled) man}

Among the many questions about the condition and perspectives of modern (disabled) man, oftentimes we find those regarding the methods of human study and development. Among them, I find communication and dialogue essential. Dialogue and work are the cornerstones of creating modern (disabled) man. Communication is a constant element of (disabled) human life, a way of communicating with people - a necessity. Communication, if recognized as such, always means "something" to "someone". Meaning is a lasting bond

${ }^{7}$ E. Cassirer, Esej o człowieku, Wydawnictwo "Czytelnik”, Warszawa 1977; R. Ingarden, Książeczka o człowieku, Wydawnictwo Lekarskie, Kraków 1987; R. May O istocie człowieka. Szkice z psychologii egzystencjalnej, Wydawnictwo Rebis, Poznań 1995. 
between the word form - signal - and its content, between people who communicate. As mentioned before, a signal is part of the physical world of "being," while a symbol and its meaning are the features of the (disabled) human world. The word "symbol" is neither abstract nor concrete, neither rational nor irrational - it is always the same as the meaning which was assigned to it ${ }^{8}$. Therefore, a Word, a Thought, a Being - create our reality, images of the past, the present, the future, their meanings, and values. Language as the most common form to articulate thought - is an active, creative force. From words to meanings and vice versa, these are the permanent directions of interpersonal relationships that take place in the process of communication, as well as in the process of education. Communication relations have a semantic basis. When a word or a wider communication does not have any meaning for the recipient, it becomes an empty sign. It may be heard, memorized, but nothing more. Word-based communications - direct, indirect, verbal and nonverbal - are the basic link between the sender and the receiver, and their meaning is the basic principle allowing for their organization and evaluation. The value of communication is the same as the cognitive, ethical, aesthetic, moral and pragmatic meaning assigned to it by the recipient. In the threefold structure of communication process, the sender attributed with specific intentions (i.e. causing a change in quality and quantity of communication, behavioral skills) appears next to the recipient, who is expected to understand the message and react according to its intention as well as the intentions of the sender. In their structure, it is important to evaluate the following:

- the source - who creates communication and why?

- what is its essence, sense, value?

- channel - how is the message communicated, to what extent is it changed, distorted?

- results - what is the estimated impact of the message, what does it change, what is the planned result?

8 J. Piaget, Psychologia i epistemologia, PWN, Warszawa 1977; J. Piaget, Równoważenie struktur poznawczych, PWN, Warszawa 1981; C.G. Jung Archetypy i symbole: pisma wybrane, Wydawnictwo Czytelnik, Warszawa 1976. 
Nowadays, we are being flooded with information. There are difficulties in selecting and using information. In the school system, teachers frequently shift and assign meaning to the communication. They select, transmit, interpret and evaluate it. It is, then, important that the recipients find what they are looking for, what they want to know, experience, recognize, incorporate into their context of meanings and their system of values. The essence of education is determined not by the external, but rather by the subjective attributions of the individual recipient determined by his or her own experience, individual meanings, and values 9 .

So far, the dominant one-sided education strategy was to teach and check what we have taught. This strategy was not always conducive to "I and Thou" meeting, perceiving not only my own cognitive field, preferences and meanings, but taking into account also the cognitive field of the other person, meanings assigned by them, recognizing their arguments and my lack of arguments, the space of consensus and discord, understanding and lack thereof. Meeting The Other in the context of common Being provides meaning and axiological direction for communication. In such relationships, (disabled) human attitude is revealed, a conceptual grid necessary for the definition of humanistic education is developed (e.g. understanding of basic concepts: freedom, responsibility, justice, truth, goodness, beauty, tolerance). In these situations, they become authentic and meaningful, built into human personality.

The symmetry of personal systems enables dialogue. M. Buber claims I become through my relation to the Thou; as I become I,

${ }^{9}$ W. Dykcik, Pedagogika specjalna wobec zagrożeń i wyzwań XXI wieku, Wydawnictwo Naukowe PTP, Poznań 2010; Z. Gajdzica, Człowiek z niepełnosprawnościa w rezerwacie przestrzeni publicznej, Oficyna Wydawnicza „Impuls”, Kraków 2013; L. Hurło, D. Klus-Stańska, M. Łojko, Paradygmaty współczesnej dydaktyki, Oficyna Wydawnicza „Impuls”, Kraków 2009; D. A. Michałowska, Wartości w świecie edukacji na początku XXI wieku, Wydawnictwo Naukowe UAM, Poznań 2013; B. Śliwerski, Pedagogika dziecka: studium pajdocentryzmu, Gdańskie Wydawnictwo Psychologiczne, Gdańsk 2007. 
I say Thou ${ }^{10}$. This assumption is not fully achievable in the school context. Cognitive fields, the experiences of the two communicating parties are too different, the meanings are divergent, so are the arguments and lack thereof. Thus, the educational dialogue needs to be approached gradually. Pedagogues distinguish several stages of this process:

- informational stage - preparation for dialogue in terms of substance, formal; the important and necessary elements here are relevant questions, commands, and answers; careful listening to questions and answers is the essence of this stage ${ }^{11}$;

- negotiation stage - search for cognitive, ethical and aesthetic convergence and divergence in wider areas and broader relationships, striving for consensus and acceptance.

At every stage of the school dialogue, asymmetrical by nature, there exists a cognitive and axiological convergence and divergence area between the sender and the recipient. There is always a space to fill "in-between"12. Modern education is a "constant being" between what we accept and what we want to achieve, what we want to put in "our" order. In the education system and throughout our lives, we constantly organize, accept, use and still have more to organize, accept and rule out. There is no end, there is no once-andfor-all solution. We are constantly exploring, extracting, verifying various meanings and values, and striving for the highest qualities of humanity ${ }^{13}$. It is very difficult to assign and receive cognitive, pragmatic, axiological meanings. Multiple messages, signs, symbols constantly multiplied by various technical devices, external and

${ }^{10}$ M. Buber, Ja i Ty. Wybór pism filozoficznych, Instytut Wydawniczy „Pax”, Warszawa 1992.

${ }^{11}$ A. Folkierska, Ksztatcace funkcje pytania. Perspektywy humanistyczne, [w:] Odmiany myślenia o edukacji, red. J. Rutkowiak, Oficyna Wydawnicza „Impuls”, Kraków 1995, s. 155-176; A. Folkierska, Pytanie o pedagogikę, Wydawnictwo UW, Warszawa 1990.

${ }^{12}$ T. Żółkowska, Ja, Ty, Inny - Dialog?, „Studia Edukacyjne” 2013, nr 28, s. 17-30.

${ }^{13}$ A. Grzegorczyk, Filozofia czasu próby, Instytut Wydawniczy „Pax”, Warszawa 1984. 
internal situations, put us all and the whole education system in a difficult position. More and more questions arise regarding the criteria for selecting information. How to protect oneself from the devastating dispersion of interests, the loss of meanings important to (disabled) man not only today. It seems necessary to develop attention, reflection, and not just hasty living 14 . We seek answers to such questions every day. We try to agree on the meanings of communication, distinguish between those that we will learn, study, accept, instill in ourselves and others to shorten the distance between I and Thou, between the various theoretical concepts and methodological approaches. Perhaps, we will come to such attention and awareness that the acknowledged and assigned meanings will penetrate through all the cognitive and axiological levels of entire groups of people and ourselves. Also, despite being flooded with a massive amount of information by the modern world, we will perhaps understand each other well and communicate even better, focusing on common values to understand (disabled) human, not only because he is an unfathomable mystery, but also "to ensure the world he lives in does not blow up"15.

\section{References}

Buber M., Ja i Ty. Wybór pism filozoficznych, Instytut Wydawniczy „Pax”, Warszawa 1992.

Cassirer E., Esej o człowieku, przeł. A. Staniewska, Wydawnictwo „Czytelnik”, Warszawa 1977.

Chrzanowska I., Problemy edukacji dzieci i młodzieży z niepetnosprawnościa, Oficyna Wydawnicza „Impuls”, Kraków 2010.

Dykcik W., Pedagogika specjalna wobec zagrożeń i wyzwań XXI wieku, Wydawnictwo Naukowe PTP, Poznań 2010.

${ }^{14}$ I. Chrzanowska, Problemy edukacji dzieci i młodzieży z niepetnosprawnościa, Oficyna Wydawnicza „Impuls”, Kraków 2010.

${ }^{15}$ J. Tischner, Świat ludzkiej nadziei. Wybór szkiców filozoficznych, Wydawnictwo Znak, Kraków 2000. 
Folkierska A., Kształcace funkcje pytania. Perspektywy humanistyczne, [w:] Odmiany myślenia o edukacji, red. J. Rutkowiak, Oficyna Wydawnicza „Impuls”, Kraków 1995, s. 155-176.

Folkierska A., Pytanie o pedagogike, Wydawnictwo UW, Warszawa 1990.

Gadamer H.G., Semantyka i hermeneutyka, [w:] H.G. Gadamer, Rozum, stowo, dzieje. Szkice wybrane, wybrał K. Michalski, Państwowy Instytut Wydawniczy, Warszawa 2000.

Gadamer H.G., Prawda i metoda, Wydawnictwo Naukowe PWN, Warszawa 2007.

Gajdzica Z., Człowiek z niepetnosprawnościa w rezerwacie przestrzeni publicznej, Oficyna Wydawnicza „Impuls”, Kraków 2013.

Gnitecki J.,, Metodologia badań w pedagogice hermeneutycznej: hermeneutyczna zmiana formacyjna w pedagogice, Wydawnictwo Naukowe PTP, Poznań 2007.

Grzegorczyk A., Filozofia czasu próby, Instytut Wydawniczy „Pax”, Warszawa 1984.

Heidegger M., Bycie i czas, Wydawnictwo Naukowe PWN, Warszawa 2007.

Hurło L., Klus-Stańska D., Łojko M., Paradygmaty współczesnej dydaktyki, Oficyna

Wydawnicza „Impuls”, Kraków 2009.

Ingarden R., Książeczka o człowieku, Wydawnictwo Lekarskie, Kraków 1987.

Jung C.G., Archetypy i symbole: pisma wybrane, Wydawnictwo Czytelnik, Warszawa 1976.

Kozielecki J., Transgresje jako źródto kultury, [w:] Humanistyka przełomu wieków, Wydawnictwo Akademickie "Żak”, Warszawa 1999.

Lem S., Krótkie uwagi o humanizmie, [w:] Humanistyka przełomów wieku, red. J. Kozielecki, Wydawnictwo Akademickie "Żak”, Warszawa 1999.

Lyotard J.F., The Postmodern Condition. A Report on Knowledge, https://www.marxists. org/reference/subject/philosophy/works/fr/lyotard.htm [dostęp: 7.07.2017].

Lyotard J.F., Fenomenologia, Wydawnictwo KR, Warszawa 2000.

May R., O istocie człowieka. Szkice z psychologii egzystencjalnej, Wydawnictwo Rebis, Poznań 1995.

Michałowska D.A., Wartości w świecie edukacji na początku XXI wieku, Wydawnictwo Naukowe UAM, Poznań 2013.

Piaget J., Równoważenie struktur poznawczych, PWN, Warszawa 1981.

Piaget J., Psychologia i epistemologia, PWN, Warszawa 1977.

Strelau J., Psychologia. Podręcznik akademicki, Gdańskie Wydawnictwo Naukowe, Gdańsk 2000.

Śliwerski B., Pedagogika dziecka: studium pajdocentryzmu, Gdańskie Wydawnictwo Psychologiczne, Gdańsk 2007.

Tischner J., Świat ludzkiej nadziei. Wybór szkiców filozoficznych, Wydawnictwo Znak, Kraków 2000.

Topolski J., Przyrodniczy i humanistyczny punkt widzenia w badaniach historycznych, [w:] Humanistyka przełomów wieku, red. J. Kozielecki, Wydawnictwo Akademickie "Żak", Warszawa 1999.

Żółkowska T., Ja, Ty, Inny - Dialog?, „Studia Edukacyjne” 2013, nr 28. 